\title{
Muscle-Derived Factors that Support Survival and Promote Fiber Outgrowth from Embryonic Chick Spinal Motor Neurons in Culture
}

\author{
Ulrike Dohrmann, ${ }^{1}$ David Edgar, Michael Sendtner, and Hans Thoenen \\ Max-Planck-Institute for Psychiatry, Department of Neurochemistry, D-80ss Martinsried, Federal Republic of Germany
}

Received March 7, 1986; accepted in revised form June 18, 1986

\begin{abstract}
The purpose of the experiments reported is to provide an unambiguous demonstration that embryonic skeletal muscle contains factors that act directly on embryonic spinal motor neurons both to support their survival and to stimulate the outgrowth of neurites. Cells of lumbar and brachial ventral spinal cords from 6-day-old chick embryos were separated by centrifugation in a two-step metrizamide gradient, and a motor neuron enriched fraction was obtained. Motor neurons were identified by retrogradely labeling with rhodamine isothiocyanate, and were enriched fourfold in the motor neuron fraction relative to unfractionated cells. In culture, the isolated motor neurons died within 3-4 days unless they were supplemented with embryonic chick skeletal muscle extract. Two functionally distinct entities separable by ammonium sulfate precipitation were responsible for the effects of muscle extracts on motor neurons. The 0-25\% ammonium sulfate precipitate contained molecules that alone had no effect on neuronal survival but when bound to polyornithine-coated culture substrata, stimulated neurite outgrowth and potentiated the survival activity present in muscle. Most of this activity was due to a laminin-like molecule being immunoprecipitated with antisera against laminin, and immunoblotting demonstrated the presence of both the $A$ and $B$ chains of laminin. A long-term survival activity resided in the $25-70 \%$ ammonium sulfate fraction, and its apparent total and specific activities were strongly dependent on the culture substrate. In contrast to the motor neurons, the cells from the other metrizamide fraction (including neuronal cells) could be kept in culture for a prolonged time without addition of exogenous factor(s). 1986 Academic Press, Inc.
\end{abstract}

\section{INTRODUCTION}

Nerve cells of vertebrate embryos are generally produced in excess, and a significant portion of them dies before maturity. This natural cell death occurs during a restricted time period and is not genetically preprogrammed. Its extent is determined largely by the size of the target tissue to which the neurons project. The epigenetic regulation of neuronal survival is thought to be via specific, soluble and retrogradely transported factors that are supplied by target cells. Limited synthesis of neurotrophic factor(s) and competition for it would then be the cause of neuronal death during development (for reviews see Oppenheim, 1981; Berg, 1982; Cunningham, 1982; Hamburger and Oppenheim, 1982; Oppenheim, 1985).

The phenomenon "natural cell death" and the role of the target have been shown very clearly for chick spinal motor neurons that depend on their peripheral target, skeletal muscle, during a critical period (see Hamburger, 1977; Slack et ah, 1983). Motor neuron cell death in the chick starts at Embryonic Days 5.5-6, (E5.5-6), a time at which the motor neurons have differentiated and assembled in the lateral motor columns, their axons projecting correctly to the peripheral target sites (Land-

${ }^{1}$ To whom correspondence should be addressed. messer and Morris, 1975; Hollyday and Hamburger, 1977; Tosney and Landmesser, 1985). Approximately $40 \%$ of the motor neurons die within the following 5-6 days (Hamburger, 1975; Oppenheim et al, 1978; Oppenheim and Majors-Willard, 1978; Laing, 1982). However, the extent of motor neuron death can be decreased or increased by removal or enlargement, respectively, of peripheral target tissue (Shorey, 1909; Hamburger, 1934; Hamburger, 1958; Hollyday and Hamburger, 1976). Survival is also impaired by mutations predominantly affecting muscle (Lanser and Fallon, 1984; Stewart et al., 1984). It has thus been proposed that embryonic motor neurons require muscle-derived trophic factors for survival (for reviews see Berg, 1982; Hamburger and Oppenheim, 1982). However, no trophic molecule for motor neurons has yet been isolated.

Only three neurotrophic proteins have been identified and purified by virtue of their ability to support the survival of peripheral neurons in vitro (Levi-Montalcini and Angeletti, 1968; Barde et al, 1982; Barbin et al, 1984), but only nerve growth factor, NGF (Levi-Montalcini and Angeletti, 1968), has been shown to have a trophic role in vivo (for discussion see Barde et al., 1983). A prerequisite for the purification of these factors was that relatively homogeneous populations of peripheral neurons free of glial cells could be isolated. The extent of neuronal survival in culture was used as a bioassay for neuro- 
trophic activity (see Barde et al, 1983). In contrast to the relatively simple organization of the peripheral nervous system, the complexity of the central nervous system (CNS) made it much more difficult to isolate defined populations of neurons. Consequently the establishment of convenient bioassays for determination of neuronal survival is difficult, and progress in the isolation of neurotrophic molecules for CNS neurons has been correspondingly slow.

Many attempts using tissue culture have been made to determine the presence of activities in extracts of muscle or muscle-conditioned medium that affect embryonic motor neurons. For example it has been shown that cells dissociated from early embryonic chick, rat, or mouse spinal cords can be maintained in culture, and that media taken from cultured muscle cells or soluble extracts of muscle tissue increased the levels of cell survival, neurite outgrowth, and/or transmitter synthesis (see, e.g., Giller et al, 1977; Bennett et al, 1980; Brookes et al, 1980; Godfrey et al., 1980; Henderson et al, 1981; Longo et al., 1982; Tanaka and Obata, 1982; Tanaka and Obata, 1983; Smith and Appel, 1983; Kaufman et al, 1985; Smith et al, 1985). The fact, however, that motor neurons were not separated from other spinal cells makes the interpretation of these results ambiguous because it is not possible to decide whether the observed effects result from a direct action on the neurons in question or an indirect effect via other neuronal or nonneuronal cells (see Fukada, 1980).

Recently, techniques have become available to identify and isolate single populations of CNS neurons. Retrograde axonal transport of horseradish peroxidase or fluorescent probes permits the identification of neurons that project to a defined terminal field. It is thus possible to identify motor neurons by injecting their target muscles with horseradish peroxidase (Lamb, 1976; Bennett et al., 1980; Tanaka and Obata, 1983) or fluorescein conjugates (Eagleson and Bennett, 1983; Calof and Reichardt, 1984). The latter technique has the advantage that the fluorescently labeled motor neurons can then be isolated by fluorescence-activated cell sorting (Eagleson and Bennett, 1983; Calof and Reichardt, 1984), but it has the disadvantage that relatively small numbers of motor neurons are recovered due, for example, to retention of cells within the sorting system (Calof and Reichardt, 1984). Recently Schnaar and Schaffiner (1981) have described a centrifugation method utilizing metrizamide density gradients to separate spinal motor neurons from other cell types, based on their lighter buoyant densities. We have adapted this methd to provide a rapid and reproducible way of isolating motor neurons that can be unambiguously identified by labeling with rhodamine isothiocyanate (Thanos and Bonhoeffer, 1984).
Using purified cultures, it has been previously shown that cultured muscle cells produce a survival-promoting activity for motor neurons (Schnaar and Schaffner, 1981; Eagleson and Bennett, 1983; Calof and Reichardt, 1984). Furthermore, an activity that stimulates neurite outgrowth from motor neurons has been identified and shown to have structural and antigenic similarities with the basement membrane protein, laminin (Calof and Reichardt, 1985). It has, however, been shown previously that organ explants can begin to produce neuronal survival factors when brought into culture, although no such activity was detectable in the intact tissue (Harper et $a l, 1980$; Ebendal et al, 1980; Barth et al., 1984). In order to determine if muscle tissue in vivo does, indeed, contain survival-promoting activities or stimulates neurite outgrowth directly from motor neurons as implied by previous results (Henderson et al, 1984; Smith and Appel, 1983), we have quantitatively determined the influence of muscle extracts on survival and neurite outgrowth of purified cultures of motor neurons.

\section{MATERIALS AND METHODS}

Materials. Poly-DL-ornithine $\mathrm{HBr}$, type IB (PORN), deoxyribonuclease I (DNase), and rhodamine B isothiocyanate were obtained from Sigma. Metrizamide and trypsin were purchased from SERVA and Worthington, respectively. PANSORBIN and $N$-hydroxyethyl-4-(1naphthylvinyl)pyridium bromide (NVP) were from Calbiochem. ${ }^{125}$-Protein $\mathrm{A}(2-10 \mu \mathrm{Ci} / \mu \mathrm{g})$ was obtained from New England Nuclear Products. Liquid Leibovitz L15 medium was from Gibco. $\left[1-{ }^{14} \mathrm{C}\right]$ Acetyl coenzyme A (5 $\mu \mathrm{Ci} /$ mmole) was synthesized in our department by $\mathrm{A}$. Braun from $\left[{ }^{14} \mathrm{C}\right]$ acetic anhydride and coenzyme $\mathrm{A}$ according to Oesch et al. (1973). Mouse sarcoma laminin was a gift from Dr. R. Timpl (Max-Planck-Institute for Biochemistry, Martinsried, FRG). This laminin was also used to produce antilaminin antiserum by immunization of rabbits (Timpl et al, 1979). White leghorn chicken eggs were incubated in a humidified, force-draft incubator at $37^{\circ} \mathrm{C}$. The medium used for cell culture and for most of the steps during dissociation was L15 supplemented with $25 \mathrm{U} / \mathrm{ml}$ penicillin and $25 \mu \mathrm{g} / \mathrm{ml}$ streptomycin sulfate. L15 was further supplemented according to Mains and Patterson (1973) except that $2.5 \mathrm{mM}$ glutamine and $20 \mathrm{mM}$ glucose were used, and methocel was omitted. In addition, $10 \%$ heat-inactivated horse serum and $10 \mathrm{mM} \mathrm{KCl}$ were added ( $\mathrm{L} 15 \mathrm{H} 10)$. The $\mathrm{L} 15$ medium was shown to support chick spinal neuron survival better than F14 or DMEM, and similarly, horse serum was better than fetal calf serum (results of preliminary experiments not shown). 
Preparation of dissociated spinal cord cells. Spinal cord segments were dissected from the lumbar and brachial regions of 6-day-old chick embryos (developmental stages 28-29 according to the criteria of Hamburger and Hamilton, 1951). Twenty to thirty embryos were used for each preparation. The meninges and dorsal root ganglia were removed, the segments were divided longitudinally into the dorsal and ventral portion (Masuko et al, 1979), and the ventral portions were dissociated. After digestion with $0.05 \%$ trypsin in $\mathrm{Ca}^{2+}-\mathrm{Mg}^{2+}$-free phosphate-buffered saline (PBS) for $30 \mathrm{~min}$ at $37^{\circ} \mathrm{C}$, the tissue was washed with $5 \mathrm{ml} \mathrm{L15H10}$ containing $0.02 \%$ DNase. A single cell suspension was obtained after 10 gentle pasages through a fire-polished Pasteur pipet (approximately $1 \mathrm{~mm}$ in diameter at the tip). It was important to use a wide Pasteur pipet, and furthermore to minimize trituration; motor neuron survival was reduced by about half if cells were passed 20 times through the Pasteur pipet (data not shown). Cell debris were removed by centrifugation of the cells through a 5-mlcushion of $3.5 \%$ bovine serum albumin (BSA) in L15 for $15 \mathrm{~min}$ at $100 \mathrm{~g}$. Removal of the debris was necessary before measuring choline acetyltransferase (see below), and also cell survival was somewhat better if the cells were cultured without debris (data not shown). The pelleted cells were suspended in $5 \mathrm{ml}$ ice-cold L15.

Fractionation of spinal cord cells by metrizamide. The fractionation procedure was a modification of the method described by Schnaar and Schaffner (1981). Metrizamide was dissolved in L15, and step gradients con-

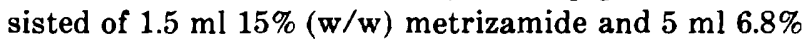
$(\mathrm{w} / \mathrm{w})$ metrizamide in siliconized glass tubes $(0.9 \times 10$ $\mathrm{cm})$. All the following steps were carried out at $2-4^{\circ} \mathrm{C}$. The spinal cord cell suspension obtained after centrifugation through the BSA was layered over the step gradient, and the tubes were centrifuged at $520 \mathrm{~g}$ for $15 \mathrm{~min}$ using a swing-out rotor. Centrifugation resulted in two layers of cells at the $0-6.8 \%$ (metrizamide fraction I) and $6.8-15 \%$ (metrizamide fraction II) interfaces. The cells from the interfaces were collected in a small volume (normally $1 \mathrm{ml}$ ). The same number of cells was recovered in the same position after refractionation (data not shown).

Retrograde labeling of motor neurons. For five experiments embryos were used in which the motor neurons had been retrogradely labeled with rhodamine isothiocyanate (Thanos and Bonhoeffer, 1984). Labeling was performed after 5 days of incubation. A small window was cut into the egg shells, and a rhodamine crystal was inserted into each limb bud. The eggs were then incubated for another $24 \mathrm{hr}$. The lumbar spinal cord fragments of the labeled embryos were dissected and either used for cell preparation or fixed in $4 \%$ formaldehyde before cutting $10-\mu \mathrm{m}$ cryostat sections. In dissociates, only cells containing strongly fluorescing granules were counted.

Choline acetyltransferase assay. Triton X-100 (final concentration $0.1 \%$; v/v) was added to aliquots taken from each step during cell preparation and cell fractionation. The samples were kept at $-20^{\circ} \mathrm{C}$ until assay for choline acetyltransferase (ChAT) by the method of Fonnum (1975). The reaction mixture contained $0.2 \mathrm{mM}$ $\left[1-{ }^{14} \mathrm{C}\right]$ acetyl coenzyme $\mathrm{A}, 600 \mathrm{mM} \mathrm{NaCl}, 16 \mathrm{mM}$ choline, $40 \mathrm{~m} M$ EDTA, $0.2 \mathrm{mM}$ eserine, $0.2 \% \mathrm{BSA}$, and $100 \mathrm{mM}$ sodium phosphate, $\mathrm{pH}$ 7.4. Substrate and cell samples, both $25 \mu$ l, were mixed and incubated for 20 and $40 \mathrm{~min}$. Blanks consisted of samples containing $1 \mathrm{mM} \mathrm{NVP}$ in order to specifically inhibit ChAT (White and Cavallito, 1970). Formation of radioactive acetylcholine was expressed as picomoles per minute, and was linear with time and with the amount of tissue sample. Furthermore, the amount of ChAT activity in dissociated cells was not decreased compared to that measured in lumbar and brachial spinal cord pieces directly homogenized at $4^{\circ} \mathrm{C}$ (data not shown).

Cell culture. Sixteen-millimeter wells (24-well cluster, Falcon) were used for cell culture. The surface of the wells had been coated with PORN $(0.25 \mathrm{mg}$ in $0.15 M$ $\mathrm{Na}$-borate buffer, pH 8.3; see Helfand et al, 1976) for 24 hr at $4^{\circ} \mathrm{C}$. The dishes were then rinsed with distilled water and either stored at $4^{\circ} \mathrm{C}$ or used immediately. In some experiments the culture dishes were subsequently coated with laminin (5-10 $\mu \mathrm{g}$ in PBS for $24 \mathrm{hr}$ at $4^{\circ} \mathrm{C}$ ). A neurite-promoting fraction from muscle (see below) was coated under the same conditions; the optimal concentration for the coating molecules used was determined by serial dilution according to Edgar et al. (1984). The dishes were rinsed with PBS before plating of the cells. Cells from the metrizamide gradient were suspended in $\mathrm{L} 15 \mathrm{H} 10$, and $1-2 \times 10^{4}$ cells $/ \mathrm{ml}$ were plated into the wells. Cultures were maintained at $37^{\circ} \mathrm{C}$ at $80 \%$ relative humidity in $95 \%$ air and $5 \% \mathrm{CO}_{2}$. Neuronal survival was determined by averaging counts from $10 \mathrm{mi}-$ croscopic fields (approximately $\frac{1}{16}$ of the total surface area of a culture well) in 2 separate culture wells. Initial cell numbers were determined after cell attachment (about $3 \mathrm{hr}$ after plating). The number of surviving neurons was normally counted after 5 to 6 days. The culture medium was not renewed during this time because medium changes did not alter the percentage of surviving neurons (data not shown). The specific survival activity $\left(E D_{50}\right)$ present in muscle extract was defined as the amount of protein per $\mathrm{ml}$ that was needed to support $50 \%$ of the maximally obtainable survival.

Preparation of muscle extract. Embryonic chick leg muscles (E17-19) were freed of skin and bones and frozen 
at $-70^{\circ} \mathrm{C}$ before homogenization. Thawed tissue was homogenized with a Waring blender in 4 vol of $10 \mathrm{mM}$ Tris-HCl, pH 7.5, containing $1 \mathrm{mM}$ EDTA, $1 \mathrm{mMN}$ ethylmaleimide, $1 \mathrm{mM}$ benzamidine, and $2 \mathrm{mM}$ phenylmethylsulfonyl fluoride. The homogenate was centrifuged at $23,000 \mathrm{~g}$ for $1 \mathrm{hr}$. The supernatant (crude muscle extract) was either used directly for cell survival experiments or fractionated by $\left(\mathrm{NH}_{4}\right)_{2} \mathrm{SO}_{4}$ precipitations. Fractionation was in two steps, 0-25 and 25-70\% $\left(\mathrm{NH}_{4}\right)_{2} \mathrm{SO}_{4}$, the resulting pellets being dissolved in PBS (normally one-fifth of the original volume) and designated as $A 1$ and $A 2$, respectively. All muscle extract fractions were dialyzed overnight at $4^{\circ} \mathrm{C}$ against PBS and filter sterilized before use. They were kept on ice or at $-20^{\circ} \mathrm{C}$. The protein content was determined as described by Lowry et al (1951) using BSA as the standard.

Immunoprecipitation. Fixed Staphylococcus aureus cells (PANSORBIN) were washed three times in immunoprecipitation buffer (50 $\mathrm{m} M$ Tris- $\mathrm{HCl}, \mathrm{pH} 7.5,150$ $\mathrm{m} M \mathrm{NaCl}, 0.1 \%$ sodium deoxycholate and $0.1 \%$ Nonidet), and once in this buffer with $0.25 \mathrm{mg}$ fibronectin $/ \mathrm{ml}$ added in order to prevent the direct adsorption of any fibronectin in the extract (Moshner and Proctor, 1980). PANSORBIN was then suspended in 1:10 (v/v) of immunoprecipitation buffer. A mixture of $200 \mu \mathrm{l} \mathrm{A1}, 1.4 \mathrm{ml} \mathrm{im-}$ munoprecipitation buffer, and $20 \mu l$ antilaminin antiserum or rabbit preimmune serum was shaken for $20 \mathrm{~min}$. Then $100 \mu \mathrm{l}$ PANSORBIN suspension was added, and the mixture was shaken for $2 \mathrm{hr}$. After centrifugation, the supernatants were used to coat the culture wells as described above.

Immunoblotting. One-milliliter aliquots of A1 were treated with $10 \%(\mathrm{w} / \mathrm{v})$ polyethylene glycol (approx mol wt 6000 ) in order to precipitate high molecular weight proteins. After centrifugation the pellets were dissolved in $50 \mu \mathrm{l}$ electrophoresis buffer under reducing conditions in 2-mercaptoethanol, and subjected to SDS-gel electrophoresis on 3-6\% exponential polyacrylamide gels (Laemmli, 1970). Thereafter, the proteins on the gel were transferred electrophoretically to nitrocellulose sheets according to the method of Towbin et al (1975). The sheets were then incubated at room temperature for 2 $\mathrm{hr}$ with antilaminin antiserum at a dilution of $1: 100$. After extensive washing, the sheets were incubated with ${ }^{125}$ I-labeled protein $A$ at a dilution of 1:400 at room temperature for $1 \mathrm{hr}$. Autoradiography was at room temperature.

\section{RESULTS}

Isolation of spinal motor neurons by metrizamide density gradient centrifugation. It has been reported previously that motor neurons from $\mathrm{E} 6$ chick embryos can be isolated from other spinal cells by centrifugation in metrizamide gradients (Schnaar and Schaffner, 1981). Two changes had to be made in the procedure, however: the metrizamide concentration of the upper gradient layer was increased from 6.3 to $6.8 \%$, and the centrifugal force was decreased rom 2500 to $520 \mathrm{~g}$. With the conditions reported by Schnaar and Schaffner (1981), adequate separations were seen for spinal cells of older embryos, but motor neurons older than E6 did not survive well in culture (data not shown). Possibly this can be explained by the fact that older motor neurons are larger and have more dendritic processes, and are therefore more susceptible to injury by dissection and trituration. Using older spinal cords, trituration had to be more extensive because of more connective tissue. It was not possible to separate putative motor neurons from embryos of E5 or younger by metrizamide gradient centrifugation, presumably owing to the lack of a large enough difference in buoyant densities between different spinal cells of young embryos.

When E6 spinal cells were dissociated, the proportion of large cells (putative motor neurons) was between 20 and $30 \%$ (Fig. 1A). The recovery of cells after centrifugation was approximately $80 \%$ (Table 1 ). Most of the cells were found in metrizamide fraction II (6.8-15\% interface) and only $13 \%$ of the cells were recovered in metrizamide fraction I (0-6.8\% interface). The latter consisted mainly of large phase-dark cells (mean diameter $14 \mu \mathrm{m} ; n=49$; Fig. 1B) in comparison to smaller phasebright cells (mean diameter $11.9 \mu \mathrm{m} ; n=95$ ) found in fraction II (Fig. 1C). Note that the standard error for cell numbers recovered in fraction $I$ is relatively large (Table 1), and most probably reflects slight variations in the age of the numerous (20-30) embryos dissected for single experiments.

In order to confirm that the large cells recovered in fraction I were indeed motor neurons, fractionation was performed using spinal cells from rhodamine-labeled embryos. As can be seen from cross sections of the lumbar spinal cord of an E6 embryo (Fig. 2), only motor neurons were labeled after $24 \mathrm{hr}$ of retrograde rhodamine transport in ovo. The labeling was, however, not complete: in the representative example shown in Fig. 2 , only about $30 \%$ of the right hand ventral horn motor neurons were strongly fluorescing, whereas even fewer of the left hand ventral horn cells were labeled. The labeling could be increased by a longer incubation time, but this resulted in an unacceptably high mortality rate (which was already about $50 \%$ after $24 \mathrm{hr}$ postinjection). In good agreement with the estimate of the degree of motor neuron labeling, $24 \%$ of all metrizamide fraction I cells showed strong rhodamine fluorescence, representing an enrichment of about fourfold over unfrac- 

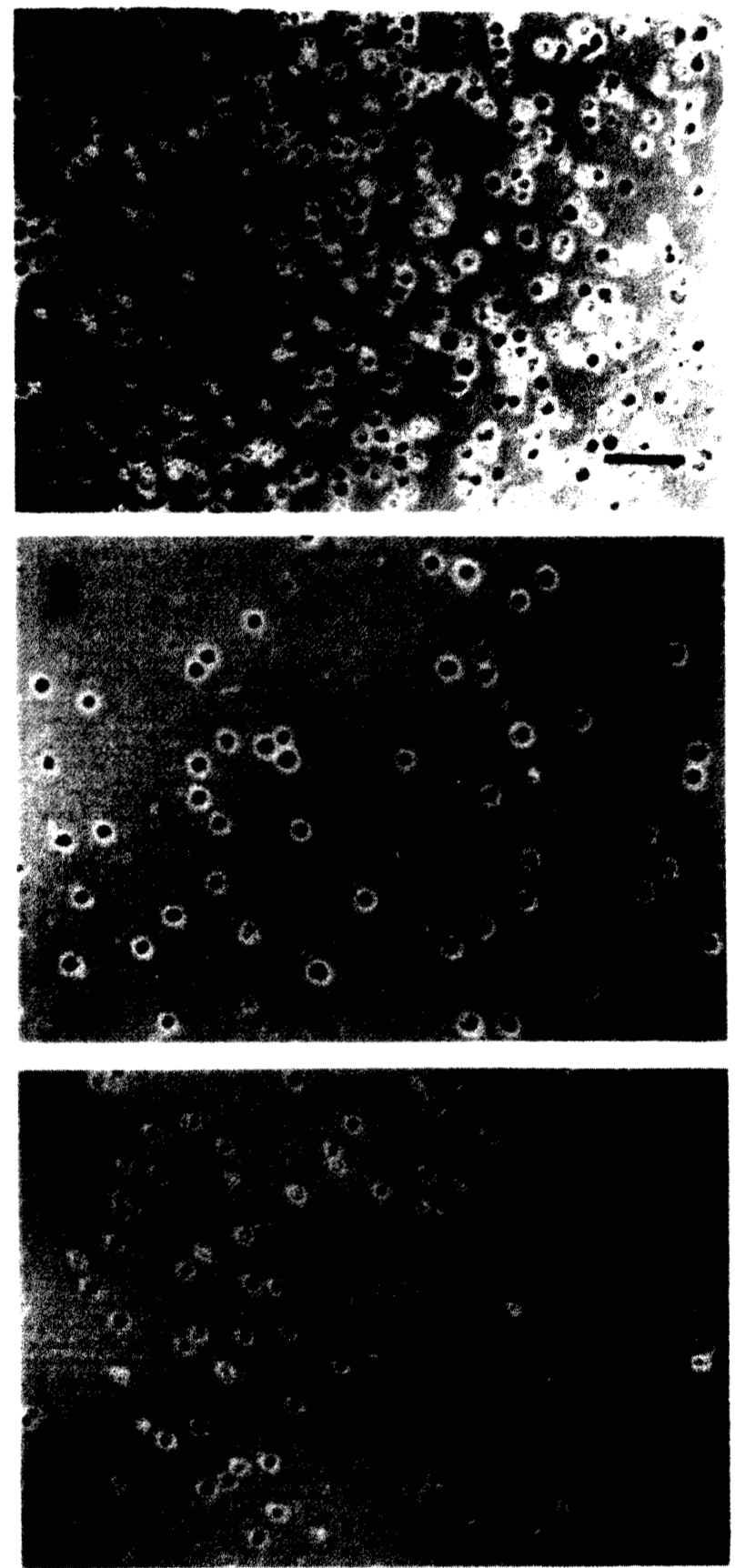

FIG. 1. Photomicrographs of spinal cells after dissociation and separation by a metrizamide step gradient. Cells from spinal cord fragments were dissociated and fractionated as described. The cells obtained from each step were suspended in culture medium and plated. Photographs were taken $3 \mathrm{hr}$ after plating when all cells had attached to the PORN substrate. (A) Unfractionated cells after centrifugation through a BSA cushion; (B) cells from metrizamide fraction I; (C) cells from metrizamide fraction II. The bar represents $100 \mu \mathrm{m}$.
TABLE 1

Fractionation of Spinal Cells on a Metrizamide Gradient: ReCOVERy OF Cells, ChAT ACTIVITY, AND RhOdAMINe-Labehled Cells

\begin{tabular}{lccc}
\hline & \multicolumn{2}{c}{ Metrizamide fraction } \\
\cline { 3 - 4 } $\begin{array}{c}\text { Cells before } \\
\text { gradient }\end{array}$ & I (0-6.8\%) & II $(6.8-15 \%)$ \\
\hline No. of cells $\left(\times 10^{-3}\right)^{a}$ & $\begin{array}{c}360 \pm 50 \\
(100 \%)\end{array}$ & $\begin{array}{c}39 \pm 13 \\
(11 \%)\end{array}$ & $\begin{array}{c}260 \pm 90 \\
(72 \%)\end{array}$
\end{tabular}

Rhodamine-labeled cells $^{b}$

Total ChAT activity ${ }^{e}$ Specific ChAT

activity ${ }^{d}$

$\begin{array}{rrr}6.2 \pm 1.5 & 23.9 \pm 2.1 & 2.9 \pm 0.6 \\ 100 \pm 12 \% & 27 \pm 3 \% & 36 \pm 6 \% \\ 100 \pm 19 \% & 298 \pm 15 \% & 42 \pm 4 \%\end{array}$

Note. Values represent the means \pm SEM of six experiments. Rhodamine-labeling experiments were performed three times.

a Number of cells derived from one spinal cord.

${ }^{b}$ Percentage of cells in each fraction that were labeled with rhodamine.

'The activity present in dissociated and debris-free cells from one spinal cord was set $100 \%$ ( $=18 \mathrm{pmole} / \mathrm{min})$.

${ }^{d}$ The activity present in $10^{6}$ dissociated and debris-free cells was set $100 \%(=50 \mathrm{pmole} / \mathrm{min})$.

tionated cells (Table 1). The proportion of rhodaminepositive cells in fraction II was approximately eight times lower than that in fraction I, although the absolute number of labeled motor neurons in fraction II was only a little lower than in fraction I $\left(9.3 \times 10^{3}\right.$ in fraction I vs $7.5 \times 10^{3}$ in fraction II; see Table 1 ).
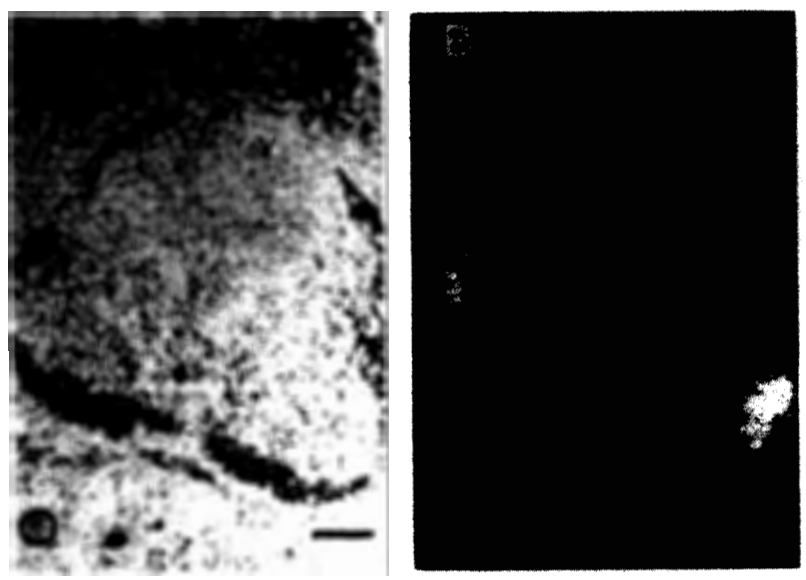

FIG. 2. Retrograde labeling of spinal cord motor neurons. The photomicrographs show a cross section through the lumbar spinal cord of an E6 chick embryo. Motor neurons were retrogradely labeled for $24 \mathrm{hr}$ in ovo by insertion of a rhodamine B isothiocyanate crystal into each limb bud. Cord fragments were then fixed in $4 \%$ formaldehyde at $4^{\circ} \mathrm{C}$ for $4 \mathrm{hr}$. After overnight washing in $25 \%$ sucrose, the tissue was frozen and $10-\mu \mathrm{m}$ cryostat sections were cut using a freezing $\mathrm{mi}$ crotome. (A) Phase-contrast photomicrograph; (B) fluorescence photomicrograph showing the location of rhodamine. The bar represents $200 \mu \mathrm{m}$. 
In line with the results of the rhodamine labeling, specific ChAT activity was enriched threefold in cells collected from fraction I vs unfractionated cells, and it was seven times lower in metrizamide fraction II than in metrizamide fraction I (Table 1). However, total ChAT activity was higher in fraction II than in fraction $I$, in contrast to the distribution of fluorescently labeled motor neurons (Table 1). It was very important to remove the debris by centrifugation through a BSA cushion before metrizamide gradient centrifugation (see Materials and Methods), as they contaminated metrizamide fraction $I$ if they were not removed. The debris collected from the BSA cushion contained $60 \pm 18 \%(\mathrm{SEM} ; n=6)$ of the total ChAT activity present in spinal cells after dissociation.

Survival of spinal cells in culture. The two fractions of spinal cells, separated by virtue of differences in their buoyant densities, also displayed differences in their behavior in culture. The motor neurons of fraction I were only able to survive and extend neurites in culture in the presence of muscle extract (Fig. 3B). Motor neuron identity throughout culture was confirmed by rhodamine fluorescence (Figs. 3E, F), and the proportion of labeled cells remained constant under all culture conditions. Without muscle extract the motor neurons died within 2-4 days, whereas in the presence of extract they could be maintained for at least 3 weeks in culture. In contrast, cultured cells from metrizamide fraction II, if plated at 10,000 or more cells/well and on laminin, survived for at least 12 days, whether or not muscle extract was present (Figs. 3C, D). The muscle extract did, however, stimulate fiber outgrowth from some of these cells, and it enhanced proliferation of flat nonneuronal cells (Fig. 3D). When fraction II cells were plated at densities higher than 10,000 cells/well with or without muscle extract (on laminin), cell survival and neurite extension were increased. However, when purified motor neurons were plated at higher densities in the presence of muscle extract, survival remained constant or was even reduced, and all cells died if cultured without extract (data not shown).

Role of muscle extract and culture substrate on motor neuron survival. Motor neurons with an appearance as seen in Figs. 3B, E, F and in Fig. 5B were obtained when culture was on laminin or neurite outgrowth-promoting activity from muscle (see below). When motor neurons were cultured on polyornithine, muscle extract was only able to support the survival of a small proportion of motor neurons plated (5.3\%;Fig. 4). This level of survival was, however, more than doubled $(11.2 \%)$ if the dishes were also coated with laminin (Fig. 4). Laminin alone was not able to support neuronal survival (all cells died as did the control cells), but rather potentiated the effect of the muscle extract. Furthermore, laminin shifted the dose-response curve to the left (in the typical experiment shown in Fig. 4, the $\mathrm{ED}_{50}$ was decreased from 65 to 27 $\mu \mathrm{g} / \mathrm{ml}$ ). Laminin substrates were not, however, able to prevent the toxic activity seen when higher concentrations of muscle extract were used. In addition to its potentiating effect on motor neuron survival, laminin markedly stimulated the growth of neurites (Fig. 5B), so that after 4-6 days in culture all surviving neurons had neurites. Note that laminin was important for the survival of metrizamide fraction II cells as well: their plating density had to be at least 30,000 cells/well if they were to survive without exogenous factors on polyornithine alone (data not shown).

A similar but smaller neurite outgrowth-promoting activity was also seen in crude muscle extract that had been coated to polyornithine treated dishes (data not shown). This activity could be separated from the survival activity by precipitation with $25 \%$ saturated ammonium sulfate, and the precipitated fraction was designated A1. Fractionation with ammonium sulfate has been used previously in the purification of a neuritepromoting factor from medium conditioned by corneal endothelial cells (Lander et al, 1983). When coated to the culture substrate in addition to polyornithine, A1 stimulated the growth of neurites as effectively as laminin (Fig. 5C), and it potentiated the survival of motor neurons like laminin (compare Fig. 7 with Fig. 4). However, the A1 fraction had virtually no effect on neuronal survival when it was added to the cultures (Fig. 6).

In order to precipitate the survival promoting activity of muscle extract it was necessary to increase the ammonium sulfate concentration to $70 \%$ saturation (A2). The maximum number of motor neurons that survived in response to A2 was the same as that supported by the crude muscle extract, and furthermore, A2 was still inhibitory at higher concentrations (Fig. 6).

Using the survival-promoting activity of muscle it could be shown that the neurite outgrowth-promoting activity $\mathrm{A} 1$ could be largely immunoprecipitated using antilaminin antiserum (Fig. 7). Immunoblotting with this antiserum (Fig. 8) showed that on reduction A1 contained both the $A$ and $B$ chains of laminin (mol wt $440 \mathrm{~K}$ and $220 \mathrm{~K}$, respectively; see Timpl et al, 1979). Additionally, a protein of approximately $80 \mathrm{~K}-90 \mathrm{~K}$ was detected (Fig. 8) that probably is a degradation product of laminin because it is recognized by the antilaminin antiserum, and as the intensity of its staining appeared to be reciprocal to that of the $A$ chain when various western blots were compared.

\section{DISCUSSION}

The aim of this study was to develop a reproducible and efficient method to isolate and culture embryonic 

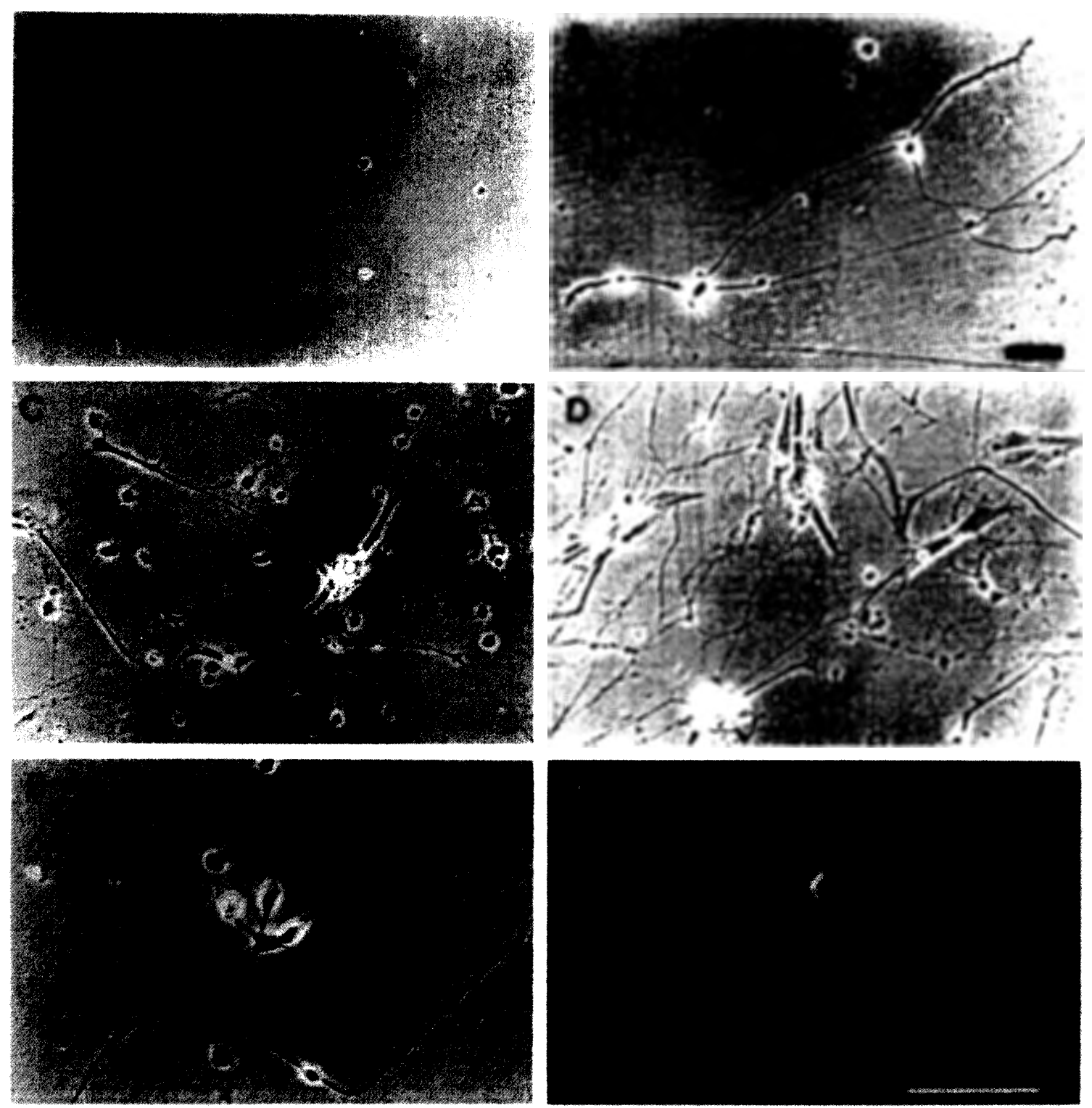

FIG. 3. Motor neurons require muscle extract for survival, cells from metrizamide fraction II do not. Metrizamide fraction I cells were plated at $2 \times 10^{4}$ cells/well (A, B) and at $1.4 \times 10^{4}$ cells/well (E, F). Metrizamide fraction II cells (C, D) were plated at $2 \times 10^{4}$ cells/well. Cells were derived from unlabeled embryos (A-D) or from embryos that had been labeled with rhodamine (E, F), where (F) is the fluorescence photomicrograph of (E). Culture dishes were coated with PORN and laminin. Crude muscle extract at an optimal concentration (100 $\mu \mathrm{g}$ protein/ $\mathrm{ml}$ ) was added to $B$ and D-F. Culture was for 6 days (E, F) and for 12 days (A-D). The bars represent $100 \mu \mathrm{m}$.

chick spinal motor neurons. The survival of these cells in culture can then be used to unambiguously identify the presence of molecules that act directly to promote motor neuron survival.

Isolation of spinal motor neurons. Chick spinal cells were dissociated from whole tissue by a combination of tryptic digestion and trituration. Some 22,000 cells identified as motor neurons (by the retrograde labeling tech- nique with rhodamine isothiocyanate) were found in the unfractionated cell suspension obtained from the ventral brachial and lumbar regions of one E6 spinal cord. Quantitative histological studies have demonstrated, however, that a total of $80,000-90,000$ motor neurons are found in these two regions at E6 (Hamburger, 1975; Oppenheim et al., 1978; Oppenheim and Majors-Willard, 1978; Laing, 1982), indicating that rhodamine labeling 


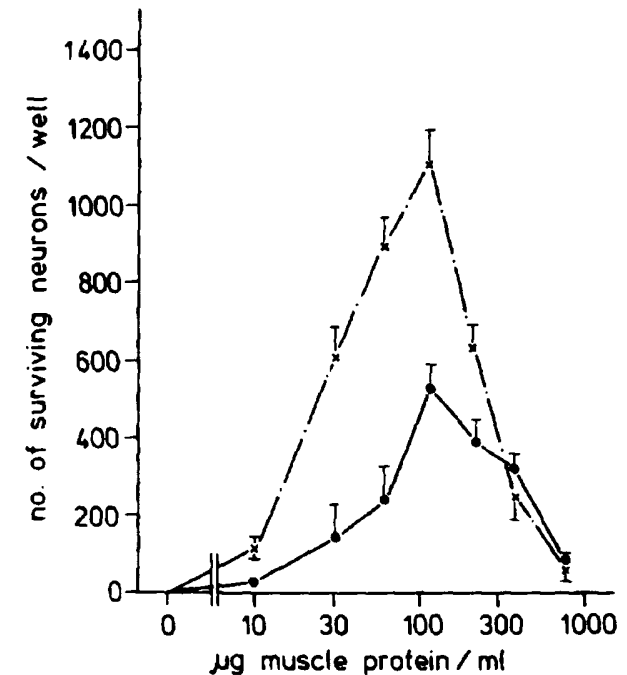

Fig. 4. The effect of culture substrate and of soluble muscle extract on the survival of cultured motor neurons. Metrizamide fraction I cells $\left(10^{4}\right.$ cells/well) were plated on PORN alone (O) or on PORN-laminin $(X)$. Crude muscle extract was added to the wells at increasing concentrations. Surviving cells were counted after 6 days. The numbers represent the means $\pm \mathrm{SEM}$ of three experiments.

only accounted for one quarter of the motor neurons originally present in vivo. It is possible that a portion of the motor neurons were destroyed by the isolation procedure. However, it is clear that the retrograde labeling method as used in the present study only marked a fraction of the motor neurons present in the ventral horns (see Fig. 2). The reason for this is that in order to maintain an adequate survival of labeled chick embryos, the labeling period had to be terminated before labeling of the ventral horn neurons was maximal.

After centrifugation, the rhodamine-labeled motor neurons collected from the $0-6.8 \%$ metrizamide interface were enriched fourfold compared with their proportion in the total cell suspension. The absolute numbers of labeled cells, however, were approximately equal in the two cell fractions obtained from the $0-6.8$ and $6.8-15 \%$ interfaces. Thus, about half the labeled motor neurons were lost from the motor neuron-enriched fraction after density gradient centrifugation. While the appearance of cells in the initial spinal dissociates was heterogeneous, the cells found in the motor neuron-enriched fraction were all very similar, being relatively large and phase-dark, thus agreeing with the morphological criteria of motor neurons as defined by Schnaar and Schaffner (1981). This observation, together with the fact that both the labeled and unlabeled cells in the motor neuron-enriched fraction behaved similarly in culture (see below) are indications that these cells constitute a homogeneous population. Other smaller and phasebright cells, with different behavior in culture, (see below) were separated into the $6.8-15 \%$ interface fraction.
The yield of cells in the motor neuron fraction obtained from the brachial and lumbar spinal cords of E6 chick embryos $(39,000 \pm 13,000)$ constitutes approximately $10 \%$
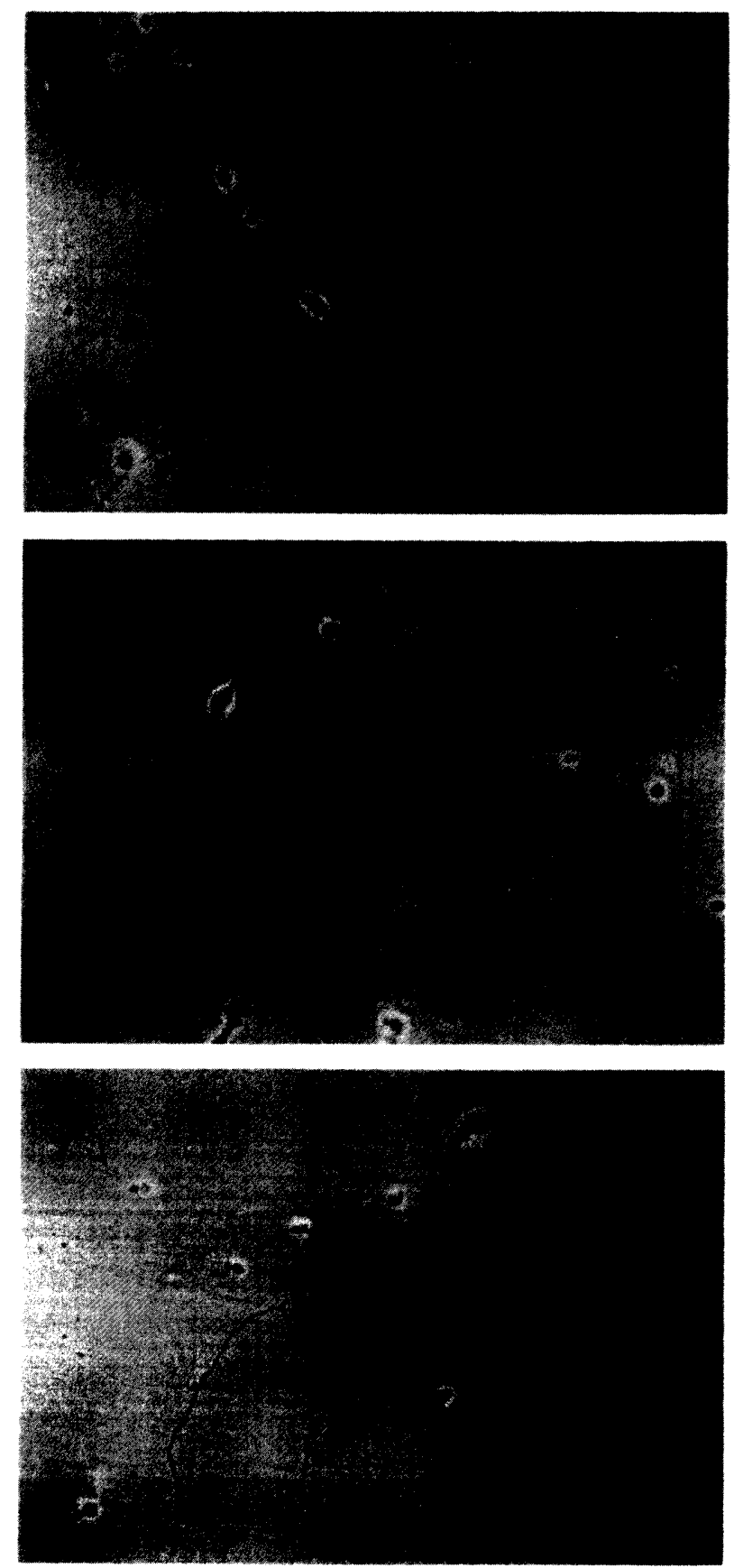

FIG. 5. Photomicrographs of motor neurons cultured on different substrata. Metrizamide fraction I cells were plated on PORN alone (A), PORN-laminin (B), and PORN-A1 (C). Al protein for coating was $6.8 \mu \mathrm{g} /$ well. A2 was added to all wells at an optimal concentration ( 75 $\mu \mathrm{g}$ protein/ml). Surviving cells were photographed 6 days after plating. The bar represents $100 \mu \mathrm{m}$. 


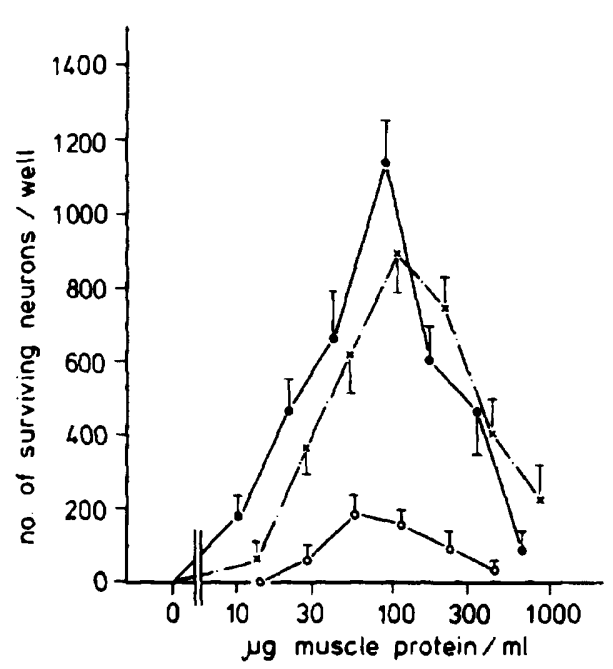

FIG. 6. Influence of crude muscle extract and fractions of muscle extract on the survival of cultured motor neurons. Metrizamide fraction I cells were plated at $10^{t}$ cells/well on PORN-laminin. Increasing concentrations of crude muscle extract $(X), A 1(O)$, or $A 2(\bullet)$ were added to the wells. Surviving cells were counted after 6 days. The means \pm SEM of four cultures are shown.

of the total number of cells dissociated from the ventral cord fragments (Table 1), and is about half the total number of spinal motor neurons to be expected in these regions (see above). The result is in disagreement with

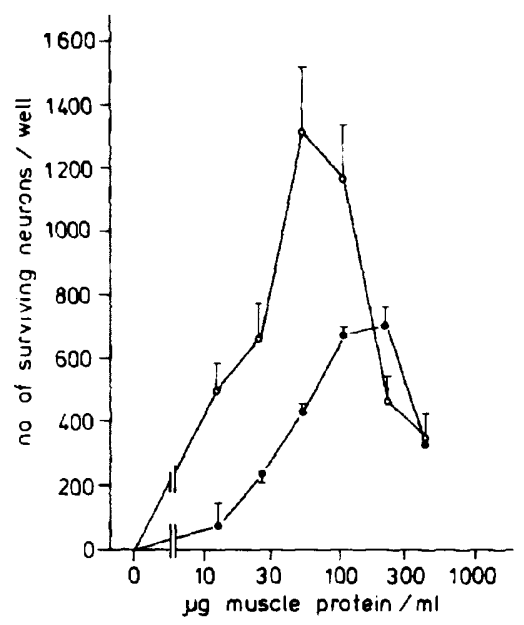

FIG. 7. Immunoprecipitation of the muscle-derived neurite-promoting activity $A 1$ with antilaminin antiserum decreases the survival of motor neurons cultured on A1. PORN-coated wells were coated with A1 that had been immunoprecipitated with antilaminin antiserum ( $)$ or with untreated A1 (6.8 $\mu \mathrm{g}$ protein/well; $O$ ). Metrizamide fraction I cells (1.5 $\times 10^{4}$ cells/well) were plated, and increasing concentrations of A2 were added to the wells. Culture was for 6 days. The bars indicate the SEM of four cultures. Preimmune serum alone precipitated one quarter of the neurite-promoting activity present in A1. Maximal survival on A1 that had been immunoprecipitated with antilaminin antiserum was $5 \%$ higher than maximal survival on PORN alone.

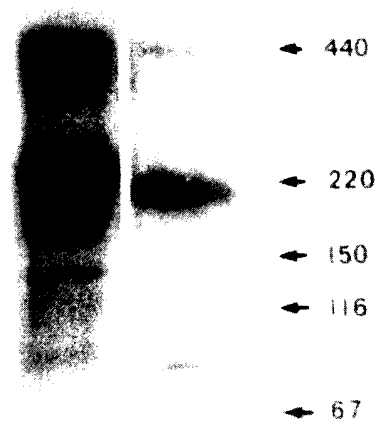

FIG. 8. Detection of laminin in the muscle-derived A1 fraction by western blot analysis. A1 (100 $\mu$ g protein) was precipitated with PEG, and subjected to SDS-gel electrophoresis under reducing conditions in a 3-6\% gradient gel. After electrophoretic transfer to a nitrocellulose filter, the filter was incubated with antilaminin antiserum followed by ${ }^{12}$ I-protein $A$. An authentic laminin standard ( $2 \mu \mathrm{g} /$ lane) was run in parallel. The molecular weights of standard proteins are shown (laminin $=440 \mathrm{~K}, 220 \mathrm{~K}$; bovine $\gamma$-globulin $=150 \mathrm{~K} ; \beta$-galactosidase $=$ $116 \mathrm{~K} ; \mathrm{BSA}=67 \mathrm{~K}$ ). Right lane $=\mathrm{A} 1$, left lane = laminin.

that of Schnaar and Schaffner (1981) who determined that their motor neuron fraction constituted approximately $16 \%$ of the cells found in the whole spinal cord. Their motor neuron-enriched fraction therefore contained at least 400,000 cells per spinal cord, which is clearly much larger than the total number of motor neurons expected at E6. Thus the motor neuron fraction prepared by the method described by Schnaar and Schaffner (1981) must include cell types other than motor neurons, and this has to be taken into account when interpreting data obtained using such a heterogeneous population of neurons (see below).

We also determined ChAT activity because it is a reliable marker for motor neurons, and has thus been used to follow motor neuron behavior both during spinal cell fractionation (Schnaar and Schaffner, 1981), and during culture of mixed spinal cells (see e.g., Giller et al., 1977; Brookes et al, 1980; Kaufman et al, 1985) or in motor neuron-enriched spinal cultures (Flanigan et al., 1985). During the dissociation of neurons from the spinal cord we noted that approximately $60 \%$ of the enyzme activity could be found in cell-free supernatants that contained only debris, as observed by phase contrast microscopy. Presumably the enzyme had been lost from neurons during the dissociation procedure as their axonal and dendritic processes were severed. Because the debris (and therefore cell-free ChAT activity) were found to contaminate the motor neuron fraction of the metriza- 
mide gradients, it was necessary to separate the cells by precentrifugation through a cushion of $3.5 \%$ bovine serum albumin. When mixed spinal cells free from debris were fractionated in metrizamide gradients, about onequarter of the total ChAT activity was found in the motor neuron fraction. This represents a threefold enrichment of specific ChAT activity (per cell). This is a little lower than the enrichment seen when rhodamine labeling was followed. Significantly, however, more total ChAT activity was found in the $6.8-15 \%$ fraction than in the motor neuron fraction, whereas in the case of rhodamine labeling, more marked cells were found in the motor neuron fraction. These results indicate that small, unmarked, ChAT-containing cells are present in the dissociate of E6 spinal cord. The presence of cholinergic cells other than motor neurons in the chick spinal cord has also been suggested by Oppenheim et al. (1978), who showed that after limb ablation, the loss of ChAT enzymatic activity from spinal cords was considerably smaller than the $90 \%$ loss of motor neurons. Furthermore, immunohistological studies have demonstrated that besides motor neurons, other cholinergic neurons are present in the spinal cord of the neonatal rat (Phelps et $a L, 1984$ ). Taken together these observations limit the use of ChAT as a marker for the presence or behavior of spinal motor neurons in mixed cultures or explants.

Survival of spinal motor neurons in culture. In the absence of added muscle extract, all the neurons in the motor neuron fraction died withn 2-3 days in culture, irrespective of the culture substrate used. In the presence of an optimal concentration of muscle extract, together with a suitable culture substrate (polyornithine coated with either laminin or a partially purified fraction from the muscle extract; see below), then it was possible to rescue maximally $15 \%$ of the neurons originally brought into culture. Those neurons surviving after 3 days in culture could then be maintained for up to 3 weeks without significant losses. As the proportion of rhodaminelabeled cells remained constant throughout the culture period, the behavior of the cell population as a whole in this fraction was representative of spinal motor neurons. Indeed, it is likely that the vast majority of cells present were motor neurons, in the light of the arguments presented above and their homogenous behavior in culture. Thus, under adequate culture conditions it is clear that at least some spinal motor neurons can survive for extended periods of time in culture, their survival rate not being enhanced by increasing the plating density, i.e., these cultures lack endogenous survival factors.

However, why should only $15 \%$ of the motor neurons brought into culture be able to survive? Clearly there are several possibilities. For example, the trophic support provided by muscle extracts used at higher concentrations was limited, being masked by the presence of a cytotoxic activity. Additionally, the degree of damage inflicted on these comparatively large (and consequently fragile) cells may have been such that only a minor proportion of them are able to recover and survive, even in the presence of optimal trophic support. In favor of this possibility are the observations that the survival rate varied from experiment to experiment, when the most likely variable was that differing degrees of damage had been done during trituration. Furthermore, it proved increasingly difficult to isolate and culture motor neurons from chicks of embryonic age older than E6, as the motor neurons became larger and even more fragile. $A$ further possibility to account for the low survival rate is that the culture conditions were inadequate. In favor of this are the observations that the culture substrate was of vital importance if maximal survival rates in response to soluble muscle extract were to be achieved (see below). Furthermore, any intrinsic spinal factors that might influence the motor neurons (see Cunningham, 1982, for discussion) have not been investigated in this study. It has previously been shown that both descending and sensory afferents to the lateral motor columns are necessary for optimal survival of spinal motor neurons in vivo (Okado and Oppenheim, 1984). Furthermore, trophic support could come from glial cells, and glial cells have been shown to produce neurotrophic factors (see Barde et $a l, 1983$ ) and neurite outgrowth-promoting factors (Adler et al, 1981). Thus the lack of a suitable support from the spinal cord might well explain the high losses seen in culture, even in the presence of muscle extracts. Indeed, preliminary experiments (results not shown) indicate that the survival of (labeled) motor neurons can at least be doubled in the presence of other spinal cells (see Manthorpe et al., 1983, for the effect of other spinal cells on ChAT activity), and that this effect is additive to that of the muscle extracts.

In contrast to the dependence on muscle extract shown here for motor neuron survival, Flanigan et al (1985), using the purification technique of Schnaar and Schaffner (1981), have recently shown that a large number (approximately $40 \%$ of those brought into culture) of neurons in a motor neuron-enriched fraction would survive for at least three days even in the absence of muscle extract. While it is possible that the collagen gel used in that study was responsible for the high survival rates as suggested by these authors (Flanigan et al, 1985), we think it is more likely to be due to the high cell densities used $(500,000$ cells per $16-\mathrm{mm}$ well), and the probability that neurons other than motor neurons (see discussion of the gradient isolation technique above) were present in the reaggregating cultures. Also the ChAT activity measured in that study might have been due, in part, to the presence of cholinergic interneurons (see above).

In contrast to the motor neurons, the cells present in the $6.8-15 \%$ neuronal fraction did not require muscle extract in order to survive in culture, as has been also 
previously demonstrated by Schnaar and Schaffner (1981). Although many of these cells were neuronal as demonstrated by neurofilament staining (data not shown), many were flat cells that could multiply in culture and were presumably fibroblasts or glial cells (immature astrocytes). It is probable that the presence of such nonneuronal cells promoted the survival of neurons in this fraction (see Barde et al, 1983). Furthermore, crude muscle extract stimulated the proliferation of nonneuronal cells and, thus, may have enhanced neuronal survival by an indirect effect.

In addition to the need for muscle extract for motor neuron survival, it was found that laminin-coated polyornithine culture substrates were necessary for maximal neurite outgrowth from motor neurons as has been previously documented (Calof and Reichardt, 1984, 1985). The results presented here also show that laminin substrates potentiate the survival of the motor neurons in response to muscle extract, acting so that the maximal number of surviving neurons is increased by a factor of about two, and decreasing the amount of muscle extract needed to obtain $50 \%$ survival (see Edgar and Thoenen, 1982, for comparable effects on sympathetic neurons). The laminin substrate alone did not support neuronal survival, i.e., laminin is here acting as a potentiating factor, as has previously been shown for its action on peripheral sympathetic neurons (Edgar et al, 1984). (Note here that the survival of metrizamide fraction II cells was also dependent on the culture substrate: if the cells were to survive in absence of added factors on polyornithine at least 30,000 cells/well had to be plated. However, on polyornithine-laminin, survival of metrizamide fraction II cells without exogenous factors was already observed when 10,000 cells/well were plated.)

Given that muscle extracts do support motor neuron survival, we have begun to analyze the individual components responsible. Preliminary experiments indicated that although laminin substrates were necessary to see a maximal effect of muscle extract added to the cultures, it was possible to precoat polyornithine substrates with the muscle extract itself in order to get both stimulation of neurite outgrowth and enhancement of survival. This effect was however variable and slight compared to that of laminin, and it was only by partially purifying the activity that a reproducible stimulation of neurite outgrowth and potentiation of survival similar to that of laminin could be achieved. This is presumably due to the presence of other proteins in the crude muscle extract that inhibit binding of the neurite outgrowth-promoting molecules to the substrate. Such an inhibition would also explain why it was necessary to use laminin substrates in cultures to which muscle extract had been added in the medium in order to see an optimal neurite outgrowth. Serum proteins can block the neurite-promoting effects of laminin and laminin-like molecules by preventing their attachment to culture substrates (see Lander et al, 1985).

As previously reported for the neurite-promoting activity found in conditioned media of muscle cells (Calof and Reichardt, 1985) we could immunoprecipitate the activity in muscle extract using antilaminin antiserum. Immunoblotting showed that A1 did indeed contain laminin, both $A$ and $B$ chains of the molecule being detected. Thus large amounts of laminin, previously localized to basement membranes (Timpl et ah, 1979) are present in an apparently freely soluble form in embryonic muscle extracts. Soluble laminin has recently been shown to occur in cultured C2 mouse skeletal myoblasts and myotubes (Olwin and Hall, 1985). The presence of neurite outgrowth-promoting activities in chick muscle extract has previously been described (Henderson et al. 1984). Although that activity bound to polycationic culture substrates, no characterization of the molecule nor identification of the spinal neurons responding to it were reported. The relationship between that activity and the laminin-like molecule described here is therefore unclear. A $56 \mathrm{~K}$ protein has also been implicated in motor neuron terminal sprouting in vivo (Gurney, 1984). However, it would appear that this protein was not responsible for the neurite outgrwoth of motor neurons induced here by embryonic muscle extracts. Very recently, Hayashi and Miki (1985) have reported the purification of a neurite promoting molecule from adult chick gizzard. These authors claimed that their molecule of molecular weight $700 \mathrm{~K}$ (reduced $210 \mathrm{~K}$ ) was unrelated to laminin on the basis that there was little or no cross-reactivity with antilaminin serum. It remains to be seen if the smooth muscle of gizzard does indeed produce such a non-laminin-like neurite-promoting activity, distinct from that of skeletal muscle, or if, alternatively, the immunological cross-reactivity of chick laminin with the antisera used in that study (raised against mouse tumor laminin) was so small that it remained undetected.

The major conclusion from this study is that embryonic skeletal muscle does contain a soluble survival promoting activity for isolated spinal motor neurons. The relationship of this activity to those previously reported to increase ChAT enzymatic activity (Kaufman et al, 1985) or to prmote neuronal survival in mixed cell cultures (Smith et al, 1985) awaits the purification of the responsible molecules.

This work was supported by a grant form the International Spinal Research Trust. We thank Andrea Kussmaul and Georg Dechant for their excellent technical assistance.

\section{REFERENCES}

Adler, R., Manthorpe, M., Skaper, S. D., and Varon, S. (1981). Polyornithine-attached neurite-promoting factors. Culture sources and responsive neurons. Brain Res. 206, 129-144. 
Barbin, G., Manthorpe, M., and Varon, S. (1984). Purification of the chick eye ciliary neuronotrophic factor. $J$. Neurochem. 43, 1468-1478.

Barde, Y.-A., Edgar, D., and Thomenen, H. (1982). Purification of a new neurotrophic factor from mammalian brain. EMBO J. 1, 549553.

Barde, Y.-A., Edgar, D., and Thoenen, H. (1983). New neurotrophic factors. Annu Rev. Physiol 45, 601-612.

Barth, E.-M., Korsching, S., and Thoenen, H. (1984). Regulation of nerve growth factor synthesis and release in organ cuitures of rat iris. J. Cell Biol 99, 839-843.

BennetT, M. R., LAI, K., and NuRCombe, V. (1980). Identification of embryonic motoneurons in vitro: Their survival is dependent of skeletal muscle. Brain Res, 190, 537-542.

BERG, D. K. (1982). Cell death in neuronal development. Regulation by trophic factors. In "Neuronal Development" (N.C. Spitzer, ed.), pp. 297-331. Plenum, New York.

Brookes, N., Burt, D. R., Goldberg, A. M., and Bierkamper, G. G. (1980). The influence of muscle-conditioned medium on cholinergic maturation in spinal cord cell cultures. Brain Res 186, 474-479.

CALOF, A. L., and REICHARDT, L. F. (1984). Motoneurons purified by cell sorting respond to two distinct activities in myotube-conditioned medium. Dev. Biol 106, 194-210.

CALOF, A. L., and ReichardT, L. F. (1985). Reponse of purified chick motoneurons to myotube conditioned medium: Laminin is essential for the substratum-binding, neurite outgrowth-promoting activity. Neurosci Lett. 59, 183-189.

CunNinghaM, T. J. (1982). Naturally occurring neuron death and its regulation by developing neural pathways. Int. Rev. Cytoh 74, 163186.

EAGLESON, K. L., and BENNETT, M. R. (1983). Survival of purified motor neurons in vitro: Effects of skeletal muscle-conditioned medium. Neurasci Lett. 38, 187-192.

Ebendal, T., Olson, L., Seiger, A., and Hedlund, K. O. (1980). Nerve growth factors in the rat iris. Nature (London) 283, 25-28.

EDGAR, D., and THOENen, H. (1982). Modulation of NGF-induced survival of chick sympathetic neurons by contact with a conditioned medium factor bound to the culture substrate. Dev. Brain Res. 5, 89-92.

Edgar, D., Timpl, R., and Thoenen, H. (1984). The heparin-binding domain of laminin is responsible for its effects on neurite outgrowth and neuronal survival. EMBO J. 3, 1463-1468.

Flanigan, T. P., Dickson, J. G., and Walsh, F. S. (1985). Cell survival characteristics and choline acetyltransferase activity in motor neurone-enriched cultures from chick embryo spinal cord. $J$. Neurochem. 45, 1323-1326.

FonNUM, F. (1975). A rapid radiochemical method for the determination of choline acetyltransferase. $J$. Neurochem. 24, 407-409.

FukadA, K. (1980). Hormonal control of neurotransmitter choice in sympathetic neuron cultures. Nature (London) 287, 553-555.

Glller, E. L., JR., Neale, J. H., Blllock, P. N., Schrier, B. K., and Nelson, P. G. (1977). Choline acetyltransferase activity of spinal cord cell cultures increased by co-culture with muscle and by muscleconditioned medium. J. Cell. Biol 74, 16-29.

Godfrey, E. W., SChrier, B. K., and NeLSON, P. G. (1980). Source and target cell specificies of a conditioned medium factor that increases choline acetyltransferase activity in cultured spinal cord cells. Dev. Biol 77, 403-418.

GURNEY, M. E. (1984). Suppression of sprouting at the neuromuscular junction by immune sera. Nature (London) 307, 546-548.

HAMBURger, V. (1934). The effects of wing bud extirpation on the development of the central nervous system in the chick spinal cord. $J$. Exp. Zooh 68, 449-494.

HAMBURGer, V. (1958). Regression versus peripheral control of differentiation in motor hypoplasia. Amer. J. Anat. 102, 365-410.

Hamburger, V. (1975). Cell death in the development of the lateral motor column of the chick embryo. J. Comp. Neurol 160, 535-546.
Hamburger, V. (1977). The developmental history of the motor neuron. Neurosci. Res. Program Bull 15, (Suppl. 111), 1-37.

Hamburger, V., and Hamilton, H. (1951). A series of normal stages in the development of the chick embryo. J. Morphol. 88, 49-92.

HAMBURGER, V., and OPPENHEIM, R. W. (1982). Naturally occurring neuronal death in vertebrates. Neurosci Commun. 1, 39-55.

Harper, G. P., Al-Saffar, A. M., Pearce, F. L. and Vernon, C. A. (1980). The production of nerve growth factor in vitro by tissues of the mouse, rat, and embryonic chick. Dev. Biol 77, 379-390.

HAYASHI, Y., and MIKI, N. (1985). Purification and characterization of a neurite outgrowth factor from chicken gizzard smooth muscle. $J$. Biol Chem. 260, 14269-14278.

Helfand, S. L., SMITH, G. A., and Wessers, N. K. (1976). Survival and development in culture of dissociated parasympathetic neurons from ciliary ganglia. Dev. Biol 50, 541-547.

Henderson, C. E., Huchet, M., and ChangeuX, J.-P. (1981). Neurite outgrowth from embryonic chicken spinal neurons is promoted by media conditioned by muscle cells. Proc. Nath Acad. Sci USA 78, 2625-2629.

Henderson, C. E., Huchet, M., and Changeux, J.-P. (1984). Neuritepromoting activities for embryonic spinal neurons and their developmental changes in the chick. Dev. Biol 104, 336-347.

HOLLYDAY, M., and HAMBURGER, V. (1976). Reduction of the naturally occurring motor neuron loss by enlargement of the periphery. $J$. Comp. Neurol. 170, 311-320.

HollydAY, M., and HAMBURger, V. (1977). An autoradiographic study of the formation of the lateral motor column in the chick embryo. Brain Res. 132, 197-208.

KaUfMan, L. M., BARRY, S. R., and BARretT, J. N. (1985). Characterization of tissue-derived macromolecules affecting transmitter synthesis in rat spinal cord neurons. $J$. Neurasci $5,160-166$.

LAEMMLI, U. K. (1970). Cleavage of structural proteins during assembly of the head of bacteriophage T4. Nature (Londom) 227, 680-685.

LAING, N. G. (1982). Timing of motoneuron death in the brachial and lumbar regions of the chick embryo. Dev. Brain Res. 5, 181-186.

LAMB, A. H. (1976). The projection patterns of the ventral horn to the hindlimb during development. Dev. Biol 54, 82-99.

LANDER, A. D., FUJI, D. K., and REICHARDT, L. F. (1985). Laminin is associated with the "neurite outgrowth-promoting factors" found in conditioned media. Proc. Nath Acad. Sci. USA 82, 2183-2187.

Lander, A. D., Tomaselli, K., Calof, A. L. and Reichardt, L. F. (1983). Studies on extracellular matrix components that promote neurite outgrowth. Cold Spring Harbor Symp. Quant. Biol. 48, 611623.

LANDMESSER, L., and MoRris, D. G. (1975). The development of functional innervation in the hind limb of the chick embryo. J. Physioh (London) 249, 301-326.

LANSER, M. E., and FALLON, J. F. (1984). Development of the lateral motor column in the limbless mutant chick embryo. J. Neurasci 4, 2043-2050.

LeVi-MonTALCINI, R., and ANGeletti, P. (1968). Biological aspects of the nerve growth factor. In "Growth of the Nervous System" Ciba Found. Symp. (G. E. W. Wolstenholme and M. O'Conner, eds.), pp. 126-147. Churchill, London.

Longo, F. M., Manthorpe, M. and Varon, S. (1982). Spinal cord neuronotrophic factors (SCNTFs). 1. Bioassay of Schwannoma and other conditioned media. Dev. Brain Res. 3, 277-294.

Lowry, O. H., Rosebrough, N. J., FarR, A. L., and Randall, R. J. (1951). Protein measurement with the Folin phenol reagent. J. Biol. Chem. 193, 265-275.

Mans, R. E., and Patrerson, P. H. (1973). Primary cultures of dissociated sympathetic neurons. I. Establishment of long-term growth in culture and studies of differentiated properties. J. Cell Bio. 59, 329-345.

MANThORPE, M., LUYTEN, W., LONGo, F. M., and VARON, S. (1983). Endogenous and exogenous factors support neuronal survival and cho- 
line acetyltransferase activity in embryonic spinal cord cultures. Brain Res. 267, 57-66.

Masuko, S., Kuromi, H., and Shimada, Y. (1979). Isolation and culture of motoneurons from embryonic chicken spinal cords. Proc. Nath Acad. Sci. USA 76, 3537-3541.

Mosher, D. F., and Proctor, R. A. (1980). Binding and factor XIII, mediated cross-linking of a 27 kilodalton fragment of fibronectin to Staphylococcus aureus. Science 209, 927-929.

OESCH, F., OTTEN, U., and ThOENEN, H. (1973). Relationship between the rate of axoplasmic transport and subcellular distribution of enzymes involved in the synthesis of norepinephrin. J. Neurochem. 20, 1691-1706.

OKADO, O., and OPPENHEIM, R. W. (1984). Cell death of motor neurons in the chick spinal cord. $X$. The loss of motoneurons following removal of afferent inputs. $J$. Neurosci. 4, 1639-1652.

OLwIN, B. B., and HALL, Z. W. (1985). Developmental regulation of laminin accumulation in the extracellular matrix of a mouse muscle cell line. Dev. Biol 112, 359-367.

OPPENHEIM, R. W. (1981). Cell death of motoneurons in the chick embryo spinal cord. $V$. Evidence on the role of cell death and neuromuscular function in the formation of specific peripheral connections. $J$. Neurosci. 1, 141-151.

OPPENHEIM, R. W. (1985). Naturally occurring cell death during neural development. Trends NeuraSci. 8, 487-493.

OPPENheim, R. W., CHU-WANG, I.-W., and MADERDRUT, J. L. (1978). Cell death of motoneurons in the chick embryo spinal cord. III. The differentiation of motoneurons prior to their induced degeneration following limb-bud removal. J. Comp. Neurol. 177, 87-112.

OPPENheim, R. W., and MAJORS-WillaRD, C. (1978). Neuronal death in the brachial spinal cord of the chick is unrelated to the loss of polyneuronal innervation in wing muscle. Brain Res. 154, 148-152.

Phelps, P. E., Barber, R. P., Houser, C. R., Crawford, G. D., SALvaterra, P. M., and VAughn, J. E. (1984). Postnatal development of neurons containing choline acetyltransferase in rat spinal cord: An immunocytochemical study. J. Comp. Neurol. 229, 347-461.

SCHNAAR, R. L., and SCHAFFNER, A. E. (1981). Separation of cell types from embryonic chicken and rat spinal cord: Characterization of motoneuron-enriched fractions. J. Neurasci. 1, 204-214.
SHOREY, M. L. (1909). The effects of the destruction of the peripheral areas on the differentiation of the neuroblasts. J. Exp. Zooh 7, 2563.

SLACK, J. R., Hopkins, W. G., and PocketT, S. (1983). Evidence for a motor neuron growth factor. Muscle \& Nerve 6, 243-252.

SMITH, R. G., and APPEx, S. H. (1983). Extracts of skeletal muscle increase neurite outgrowth and cholinergic activity of fetal rat spinal motor neurons. Science 219, 1079-1081.

Smith, R. G., McManaman, J., and APPEL, S. H. (1985). Trophic effects of skeletal muscle extracts on ventral spinal cord neurons in vitro: Separation of a protein with morphologic activity from proteins with cholinergic activity. J. Cell Biol. 101, 1608-1621.

Stewart, P. A., Hayakawa, B. N., and Rathbone, M. P. (1984). Accelerated loss of motor neurons in the brachial lateral motor column in muscular dystrophic chicks. Dev. Brain Res 14, 271-277.

TanaKa, H., and OBata, K. (1982). Survival and neurite growth of chick embryo spinal cord cells in serum-free culture. Dev. Brain Res. 4, 313-321.

TANAKA, H., and Obata, K. (1983). Survival of HRP-labeled spinal motoneurons of chick embryo in tissue and cell cultures. Dev. Brain Res. 9, 390-395.

Thanos, S., and Bonhoeffer, F. (1984). Development of the transient ipsilateral retinotectal projection in the chick embryo: A numerical fluorescence-microscopic analysis. J. Comp. NeuroL 224, 407-414.

TIMPL, R., ROHDE, H., ROBEy, P. G., RENNARD, S. I., FoIDART, J.-M. and MARTIN, G. R. (1979). Laminin-a glycoprotein from basement membranes. J. Biol Chem. 254, 9933-9937.

TOSNEY, K. W., and LANDMESSER, L. T. (1985). Specificity of early motoneuron growth cone outgrowth in the chick embryo. $J$. Neurasci 5, 2336-2344

Towbin, H., Staehelin, T., and Gordon, J. (1979). Electrophoretic transfer of proteins from polyacrylamide gels to nitrocellulose: Procedure and some applications. Proc. NatL Acad. Sci USA 76, 43504354.

White, H. L., and CAVALLITO, C. J. (1970). Inhibition of bacterial and mammalian choline acetyltransferases by styrylpyridine analogues. J. Neurochem. 17, 1579-1589. 